\title{
IDENTIFICATION AND STUDY OF A PROMISING CYANBACTERIA SPECIES FOR BIOTECHNOLOGICAL APPLICATIONS
}

\author{
Maria Teresa A. P. Menescal ${ }^{a}, E^{2}$ na dos Santos Almeida ${ }^{b}$ Emerson Andrade Sales $^{c}$
}

a Industrial Engineering Post-Graduation Program (PEI), Polytechnic School, Federal University of Bahia - UFBA, Rua Aristides Novis, 2, 6th floor, Federação, CEP 40.210630, Salvador, BA, Brazil; tecapin@yahoo.com.br

${ }^{b}$ Senai Cimatec University Center, Orlando Gomes Avenue, Salvador, BA, 41650-010, Brazil; ednasa@fieb.org.br

c Laboratory of Bioenergy and Catalysis (LABEC), Polytechnic School, Federal University of Bahia - UFBA, Rua Aristides Novis, 2, 2nd floor, Federação, CEP 40.210630, Salvador, BA, Brazil; eas@ufba.br

\begin{abstract}
The present work aims to evaluate a cyanobacteria isolated from a lagoon located in Salvador regarding the potential for toxin production and growth in a controlled environment to infer about the potential for biotechnological application of its biomass. The specie was identified and analysed for the presence of cyanotoxinproducing genes using molecular methods. The growth kinetics of the microorganism were carried out in the laboratory and the results (productivity of $0.5 \mathrm{~g} / \mathrm{L}$ ) showed that this specie can be cultivated under controlled conditions. The sequencing indicated a similarity with a Brasilonema sp. and the PCR products for the detection of cyanotoxins were negative, which makes it possible to use it as food or bioactive compounds sources.
\end{abstract}

Key-words: Brasilonema sp.; Biomolecular methods; Bioprospection; Biocompounds; Bioactives.

\section{IDENTIFICAÇÃO E ESTUDO DE UMA ESPÉCIE DE CIANOBACTÉRIA PROMISSORA PARA APLICAÇÕES BIOTECNOLÓGICAS}

Resumo: O presente trabalho tem como objetivo a avaliação de uma cianobactéria isolada de uma lagoa localizada em Salvador quanto ao potencial de produção de toxinas e crescimento em ambiente controlado visando inferir sobre o potencial de aplicação biotecnológica da biomassa da mesma. A espécie foi identificada e analisada quanto a presença de genes produtores de cianotoxinas por métodos moleculares. Foram realizados a cinética de crescimento da espécie em laboratório e os resultados (produtividade de $0,5 \mathrm{~g} / \mathrm{L}$ ) mostraram que esta espécie pode ser cultivada em condições controladas. O sequenciamento indicou uma similaridade com a espécie Brasilonema sp. e os produtos da PCR para a detecção de cianotoxinas foram negativos, o que torna possível utilizá-la como fonte de alimento ou de compostos bioativos.

Palavras-chave: Brasilonema sp.; Métodos moleculares; Bioprospecção; Biocompostos; Biativos. 


\section{INTRODUCTION}

Cyanobacteria are single-celled microorganisms with prokaryotic organization, photo synthesizers (usually called blue-green algae) and which are present in most ecosystems on our planet [1]. They were responsible for the accumulation of oxygen $\left(\mathrm{O}_{2}\right)$ in the primitive atmosphere and for the appearance of ozone $\left(\mathrm{O}_{3}\right)$, which retains part of the ultraviolet radiation. In addition to being important for the production of oxygen, some of them have the capacity to absorb and fix nitrogen from the air [2,3,4]. However, some species are potentially toxin-producing, such as cyanotoxins, saxitoxins and microcystins.

There is still relatively little known about the diversity of cyanobacteria. Numerous special morphotypes are likely to be discovered through bioprospecting, especially in tropical and extreme habitats. The modern combined methodological approach, which applies molecular procedures in conjunction with other methods, allows for greater recognition and a more accurate definition of this wider diversity and the differences between existing genders $[5,6,7]$. Thus, sequencing the $16 \mathrm{~S}$ rRNA gene has been used as a standard genetic approach to delimit genera of cyanobacteria [8].

Despite their long evolutionary history and their essential importance in the different trophic chains, cyanobacteria species represent one of the most recent trends in biotechnology, since they are promising for the sustainable production of products such as food, feed, cosmetics, drugs, chemicals and chemical fuels and biofuels $[9,10]$. The growing interest in the study of cyanobacteria is due to its ability to synthesize and accumulate chemical compounds with high added value and its use as a raw material for several products of commercial interest $[11,12,13,14]$. It is worth mentioning that the cyanobacterium biomass Spirulina (Artrospira sp.) is approved by ANVISA even for human consumption.

In addition, the biomass production of this microorganisms has little impact on the environment, the means of cultivation for cyanobacteria are generally cheaper, with low consumption of water and energy in the production process, without the need to use agricultural areas, and normally gives high yield per area $[15,16]$. Thus, the attitude of expanding the studies of these raw materials to the field of biotechnology becomes paramount in this context, and in this project, it brings the advantage of evaluating and using a promising new species of cyanobacteria as an alternative raw material for industrial application

The knowledge of the presence of biomolecules in the biomass cyanobacteria and its mechanism of action, in addition to the scientific contribution, can be a subsidy for the development of technologies that allow the use of these substances for the production of food inputs, medicines and cosmetics [17]. Due to the particular characteristics of some cyanobacteria, it is possible to consider that the prospecting of new species and products produced by these organisms are very desirable and promising initiatives. Several studies on bio composites extracted from cyanobacteria have highlighted and confirmed their bioactive activities, high protein content for food, among numerous applications $[18,19]$.

In this context, the objective of this article was to evaluate a new species of cyanobacteria, Brasilonema sp., regarding the potential for toxin production and growth in a controlled environment in order to infer about the potential for biotechnological application of its biomass.

\section{METHODOLOGY}




\subsection{Species Isolation and Molecular Biology Analysis}

\subsubsection{Isolation of the Species of Interest}

To isolate the species of interest, the sample was grown in BBM medium for 10 days, then $10 \mu \mathrm{L}$ of the sample was collected for inoculation in petri plates containing BBM agar $(2 \%)$. After observing the mass growth of microorganisms on the surface of the culture medium contained in the petri plate, procedures for isolation of the species were performed. These procedures involved repeated pecking and streaking of the species and continuous observations using an optical microscope (Zeiss Axiostar Plus). The species of interest was collected from the plate and resuspended in sterile liquid culture medium. The cultures were evaluated for the presence of contaminants species through microscopy. After obtaining the isolated cultures, a fraction of the biological material was inoculated in BBM culture medium in the liquid state in order to acquire sufficient cell mass for the identification and DNA extraction steps.

\subsubsection{Genomic DNA Extraction}

The first extraction step began with cell lysis of cyanobacteria biomass in a microtube, adding $300 \mu \mathrm{L}$ of TE buffer (Tris EDTA - pH 7.8 for DNA), glass beads (approximately $100 \mu \mathrm{L}$ ) and $300 \mu \mathrm{L}$ of the phenol/chloroform/isoamyl alcohol mixture (25:24:1) (Roth). Then, the microtubes were placed in a cell disruptor (FastPrep-24 ${ }^{\mathrm{TM}}$ 5G, MP Biomedicals). After this procedure, the microtubes were centrifuged for 5 min at 14,000 rpm, and the supernatant was removed and transferred to new $1.5 \mathrm{~mL}$ microtubes. For DNA precipitation, $100 \%$ ethanol was added until completing a volume of $1.5 \mathrm{~mL}$. Then, the microtubes were inverted 10x and centrifuged for 20 min at 14,000 rpm, and the $100 \%$ ethanol was discarded. The same procedure was used with $70 \%$ ethanol, with centrifugation for $2 \mathrm{~min}$. After the ethanol was discarded, the microtubes were placed in a heating block at $50^{\circ} \mathrm{C}$ for ethanol evaporation, and then $50 \mu \mathrm{L}$ of Milli-Q water was added.

\subsubsection{PCR Amplification of Genes}

For each pair of cyanotoxin and cyanobacteria-specific primers, PCRs were performed in a final volume of $20 \mu \mathrm{L}$. The PCR mixture contained $10 \mu \mathrm{L}$ of $2 x$ Red Taq Master Mix (mixture containing Taq DNA Polymerase, dNTPs, $\mathrm{MgCl}_{2}$ and reaction buffer at ideal concentrations for efficient DNA amplification by PCR), $2 \mu \mathrm{L}$ of template (DNA extract or ultrapure water), $1 \mu \mathrm{L}$ of each primer (16S rRNA primer, cylindrospermopsin, anatoxin, saxitoxin and microcystin) and $6 \mu \mathrm{L}$ of ultrapure water. The template used for the negative control (-) was ultrapure water.

\subsubsection{Electrophoresis}

The presence of DNA fragments after PCR was verified by electrophoresis in a $1 \%$ agarose gel diluted in TAE buffer. For $30 \mathrm{~mL}$ of agarose, $1.8 \mu \mathrm{L}$ of the stain Midori Green (Advance DNA Stain, Nippon Genetics Europe) was added to a horizontal gel apparatus (PeQlab). Five microliters of the marker (1 kb DNA Ladder, New England Biolabs) and $10 \mu \mathrm{L}$ of PCR products were added to each well. The running buffer used was $1 \mathrm{x}$ TAE, and the tension used was 120 volts. The DNA bands in the gel were 
visualized under UV light in a transilluminator (Phase), and photographs were taken with a Cannon camera.

\subsubsection{Band Extraction and Sequencing}

The bands resulting from PCR amplification were excised from the gel, and the DNA was extracted with the DNA Gel Extraction kit (Monarch) following the manufacturer's instructions. After extraction, the purified DNA was sent for sequencing at GATC Biotech. The results of the nucleotide sequences obtained were compared with the sequences deposited in the BLAST (Basic Local Alignment Search Tool) database.

\subsection{Species Cultivation and Biomass Productivity}

\subsubsection{Inoculums Preparation}

The Bold's Basal Medium - BBM (fresh water), whose composition can be seen in Table 1, was used for the growth of cyanobacteria. After sterilizing the flasks and the culture medium (autoclaved at $121^{\circ} \mathrm{C}$ for $30 \mathrm{~min}$ ), the specie was inoculated. After being cultivated in the BBM medium, was used as a pre-inoculum to start the experiments, in a $250 \mathrm{~mm}$ flask. $\mathrm{mL}$ with $200 \mathrm{~mL}$ of medium with $10 \%$ inoculum, in duplicate (Figure 1). The cultivation was kept without aeration, under controlled conditions of temperature $\left(26 \pm 1^{\circ} \mathrm{C}\right)$ and with artificial lighting.

\begin{tabular}{|c|c|c|c|}
\hline & Stock Solution & Amount /L & $\mathrm{mL} /$ half liter \\
\hline \multirow{4}{*}{ jolution 01} & Sodium nitrate $\left(\mathrm{NaNO}_{3}\right)$ & $25,00 \mathrm{~g}$ & \multirow{4}{*}{$10 \mathrm{~mL}$} \\
\hline & Potassiumphosphate $\left(\mathrm{K}_{2} \mathrm{HPO}_{4} \times 3 \mathrm{H}_{2} \mathrm{O}\right)$ & $9.80 \mathrm{~g}$ & \\
\hline & Monopotassiumphosphate $\left(\mathrm{KH}_{2} \mathrm{PO}_{4} \times 3 \mathrm{H}_{2} \mathrm{O}\right)$ & $17.50 \mathrm{~g}$ & \\
\hline & Sodium chloride( $\mathrm{NaCl})$ & $2.50 \mathrm{~g}$ & \\
\hline Solution 02 & Calciumchloride $\left(\mathrm{CaCl}_{2}\right.$ × $\left.2 \mathrm{H}_{2} \mathrm{O}\right)$ & $2.50 \mathrm{~g}$ & $10 \mathrm{~mL}$ \\
\hline Solution 03 & Magnesium sulfate $\left(\mathrm{MgSO}_{4} \times 7 \mathrm{H}_{2} \mathrm{O}\right)$ & $7.50 \mathrm{~g}$ & $10 \mathrm{~mL}$ \\
\hline \multirow{2}{*}{ Solution 04} & EDTA & $50,00 \mathrm{~g}$ & \multirow{2}{*}{$1 \mathrm{~mL}$} \\
\hline & Potassium hydroxide(KOH) & $31,00 \mathrm{~g}$ & \\
\hline \multirow[t]{2}{*}{ Solution 05} & Iron Sulfate $\left(\mathrm{FeSO}_{4} \times 7 \mathrm{H}_{2} \mathrm{O}\right)$ & $4.98 \mathrm{~g}$ & \multirow{2}{*}{$1 \mathrm{~mL}$} \\
\hline & Sulfuric acid $\left(\mathrm{H}_{2} \mathrm{SO}_{4}\right)$ & $1,00 \mathrm{~mL}$ & \\
\hline \multirow[t]{3}{*}{ Solution 6} & Boric acid $\left(\mathrm{H}_{3} \mathrm{BO}_{3}\right)$ & $11.42 \mathrm{~g}$ & \multirow[t]{3}{*}{$1 \mathrm{~mL}$} \\
\hline & Zinc sulfateZnSO ${ }_{4} \times 7 \mathrm{H}_{2} \mathrm{O}$ & $8.82 \mathrm{~g}$ & \\
\hline & Molybdenum trioxide $\left(\mathrm{MoO}_{3}\right)$ & $0.71 \mathrm{~g}$ & \\
\hline \multirow[t]{3}{*}{ Solution 7} & Coppersulphate $\left(\mathrm{CuSO}_{4} \times 5 \mathrm{H}_{2} \mathrm{O}\right)$ & $1.57 \mathrm{~g}$ & \multirow[t]{3}{*}{$1 \mathrm{~mL}$} \\
\hline & Cobaltnitrate $\left(\mathrm{Co}\left(\mathrm{NO}_{3}\right)_{2} \times 6 \mathrm{H}_{2} \mathrm{O}\right)$ & $0.49 \mathrm{~g}$ & \\
\hline & Magnesiumchloride $\left(\mathrm{MnCl}_{2} \times 4 \mathrm{H}_{2} \mathrm{O}\right)$ & $1.44 \mathrm{~g}$ & \\
\hline
\end{tabular}

\subsubsection{Determination of Biomass Productivity}

The growth of the specie was followed by gravimetric analysis of dry weight for 31 days, since the species is filamentous and has a large agglomeration of cells [20].

To determine dry weight, $200 \mathrm{~mL}$ of culture samples from each flask were filtered, using glass fiber filters with $0.47 \mu \mathrm{m}$ porosity (Figure 2). Before filtering the biomass, 
these filters were taken to the oven for drying during 24 hours at a temperature of $60^{\circ} \mathrm{C}$, and weighed. After filtering the biomass, the filters were taken back to the greenhouse under the same conditions as before and then weighed. The dry weight of the biomass was determined by the difference between the weighing values of the filters.

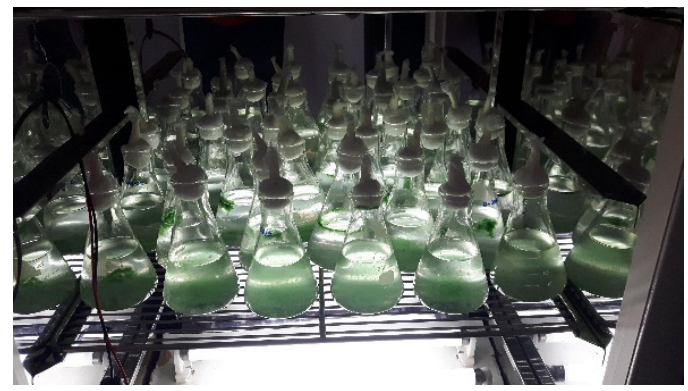

Figure 1: Cultivation of the specie in the BBM environment.

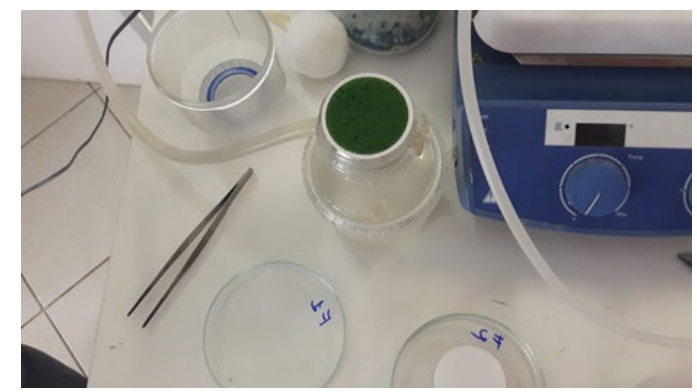

Figure 2: Biomass filtration for gravimetric analysis

\section{RESULTS AND DISCUSSION}

The isolation method used in this study was efficient to obtaining the specie of cyanobacteria from the environmental sample collected in the lake located in the city of Salvador.

DNA extraction from the isolated strain was carried out, followed by amplification of the 16S rRNA gene and gel electrophoresis, in order to confirm the presence of cyanobacterium genomic DNA in the extract, before proceeding with PCR and sequencing for cyanotoxins.

The 16S rRNA coding gene was present in the PCR reaction extract, which indicated that the specie isolated from the lake is a cyanobacteria. Having obtained this result, an excision of the PCR bands was performed with primers of the 16S rRNA of cyanobacteria (27F / $809 \mathrm{R}$ ) in order to verify the specie through sequencing.

The results of the sequencing were compared with the database available on BLAST, (Table 2). From the analysis, it was concluded that the isolated strain belongs to the genus Brasilonema sp. (Identities: 635/716 - 89\%). Currently, seven species have been discovered [21,22,23]. Six have been described in Brazil: $B$. bromeliae [21], $B$. octagenarum [22], B. epidendron, B. ornatum, B. terrestre and B. sennae [23].

Table 2 - Identification of the filamentous cyanobacteria isolate by sequencing using the BLASTIN tool

$\begin{array}{ccccc}\text { GenBank } & \text { BLASTN Result } & \text { Similarity } & \begin{array}{c}\text { Nucleotide } \\ \text { Sequence }\end{array} & \text { Accessyear } \\ \text { J30M7XJS014 } & \begin{array}{c}\text { Brasilonema terrestres train } \\ \text { CENA116 16S ribosomal RNA gene }\end{array} & 89 \% & 716 & 2019\end{array}$

Morphologically, Brasilonema presents a development composed of densely compacted fascicles, isopolar filaments, rounded apical cells not attenuated and isopolar hormonal development [21].

The results of the analysis of the PCR products using the primer pairs for the detection of cyanotoxins were negative for the cyanobacterium Brasilonema sp. This shows that the cyanobacterium species does not have the genes that encode the enzymes for the 
synthesis of cyanotoxins, which makes it possible to use it as a source of bioactive substances.

To evaluate the growth of the specie Brasilonema sp., the dry weight of the biomass ( $\mathrm{g} / \mathrm{L}$ ) was measured during 31 days (Figure 3 ). The growth data indicated that this species can be grown for biomass production under controlled conditions. Yield was recorded at $0.5 \mathrm{~g} / \mathrm{L}$. In study with cultivation of Scenedesmus sp. the authors reported a biomass concentration of $0.90 \mathrm{~g} / \mathrm{L}$ [24]. In another study, the author cultivated the species Spirulina platensis and obtained a maximum biomass concentration of 1.75 $\mathrm{g} / \mathrm{L}$ [25], and a yield of $0.98 \mathrm{~g} / \mathrm{L}$ of the species Chlorella vulgaris was observed in cultivation with BBM medium [26]. In comparison with other studies, the value obtained was slightly lower, but the production process can be optimized to increase productivity using other means of cultivation or changing its conditions. In addition, the adaptation process of the species in synthetic medium may have influenced productivity. An interesting aspect of this species is its ability to form agglomerated colonies that settle at the bottom of the culture vessel, being easily separated from the medium after the culture cycle.

Figure 3: Growth curve of Brasilonema sp.

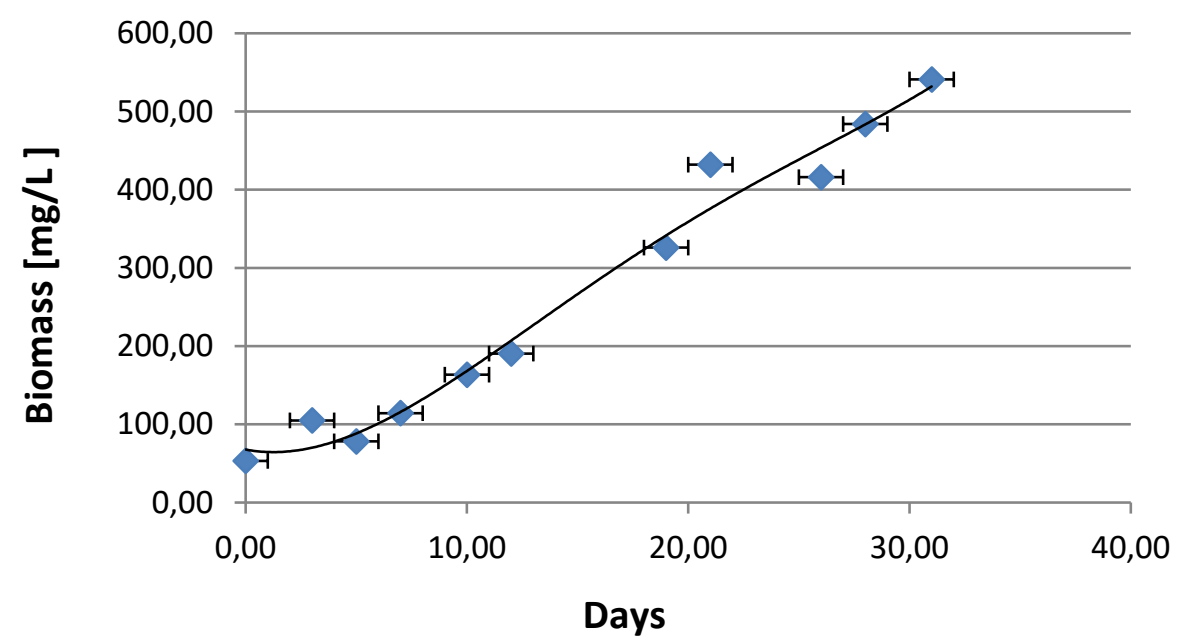

\section{CONCLUSIONS}

The results of this work demonstrate that the cyanobacteria isolated from a lake located in the city of Salvador-BA is Brasilonema sp. As this cyanobacterium specie does not have the genes that encode the enzymes for the synthesis of cyanotoxins, its biomass can be used as a raw material in several industrial sectors, including for food purposes.

This species can be cultivated under controlled conditions, however, in future works the chemical characterization of the specie' biomass will be carried out, among other studies, to optimize the biomass production and bioactive extraction processes, aiming its biotechnological applications.

\section{REFERENCES}


1. HU, Q.; SOMMERFELD, M.; JARVIS, E.; GHIRARDI, M.; POSEWITZ, M.; SEIBERT, M.; DARZINS, A. Microalgal triacylglycerols as feed stocks for biofuel production: Perspectives and advances. The Plant Journal, v. 54, n. 4,p. 621639. May. 2008.

2. KHANNA, N.; \& LINDBLAD, P. Cyanobacterial Hydrogenases and Hydrogen Metabolism Revisited: Recent Progress and Future Prospects. International. Journal of Molecular Sciences, v. 16, n. 2, p. 10537-10561.May. 2015.

3. ZEHR, J.P. Nitrogen fixation by marine cyanobacteria. Trends Microbiology, v. 19, p. 162-173. April. 2011.

4. TIWARI, A. Cyanobacteria: The Wonderful Factories. Intech Open Sep. 2018.

5. GUGGER, M. \& HOFFMANN, I.: Polyphyly of true branching cyanobacteria (Stigonematales). - Int. J. Syst. Evol. Microbiol., v. 54, n. 2, p. 349-357. Mar. 2004.

6. RAJANIEMI, P.; KOMÁREK, J.; HOFFMANN, L.; HROUZEK, P.; KAŠTOVSKÁ, K. \& SIVONEN, K. Taxonomic consequences from the combined molecular and phenotype evaluation of selected Anabaena and Aphanizomenon strains. Algological Studies, v. 117, p. 371-391. Oct. 2005.

7. BECERRA-ABSALÓN, I.; RODARTE, B.; OSORIO, K.; ALBA-LOIS, L.; SEGALKISCHINEVZKY, C. \& MONTEJANO, G. A new species of Brasilonema (Scytonemataceae, Cyanoprokaryota) fromTolantongo, Hidalgo, Central Mexico. Fottea, v. 13, n. 1, p. 25- 38. Mar. 2013.

8. RODARTE, B.; BECERRA-ABSALÓN, I.; MONTEJANO, G. A.; OSORIOSANTOS, K.; ALBA-LOIS, L.; LEÓN-TEJERA, H.;\& SEGAL-KISCHINEVZKY, C. Morphological and Molecular Characterization of Brasilonemaroberti-lamii (Cyanophyceae, Nostocales, Scytonemataceae), from Central Mexico. Phytotaxa, v. 164, n. 4, p. 255. Apr. 2014.

9. SALES, EMERSON A.; GHIRARDI, MARIA L.; JORQUERA, O.Subcritical ethylic biodiesel production from wet animal fat and vegetable oils: a net energy ratio analysis. Energy Conversionand Management, v. 141, p. 216-223, Jun. 2017.

10. ISSA, A.; ALI, E. F.; ABDEL-BASSET, R., AWAD, M. F.; EBIED, A. M.; \& HASSAN, S. A. The impact of nitrogen concentrations on production and quality of food and feedd supplements from three cyanobacteria and potential application in biotechnology. Biocatalysis and Agricultural Biotechnology, v. 23, n. 1, p. 55-62. Dec. 2020.

11. LIU, X.; \& CURTISS, R. Nickel-inducible lysis system in Synechocystis sp. PCC 6803. Proceedings of the National Academy of Sciences, v. 106, n. 51, p. 21550-21554. Dec. 2009.

12. PARMAR, A.; SINGH, N. K.; PANDEY, A.; GNANSOUNOU, E.;\& MADAMWAR, D. Cyanobacteria and microalgae: A positive prospect for biofuels. Bioresource Technology, v. 102, n. 22, p. 10163 - 10172. Nov. 2011.

13. OLIVEIRA, W. C.; OLIVEIRA C. A.; CAMPOS-GALVÃO, M. E. M.; CASTRO, V. C.; NASCIMENTO, A. G. BBR - Biochemistry and Biotechnology Reports Cyanobacteria: a review of potential nutritional and biotechnological aspects. Biochemistry and Biotechnology Reports, v. 2, n. 1, p. 49. Jan. 2013.

14. RASTOGI, R. P.; MADAMWAR, D. Cyanobacteria Synthesize their own UVSunscreens for Photoprotection. Bioenergetics: Open Access, v. 05, n. 02, jan. 2016. 
15. AL-HAJ, L.; LUI, Y.; ABED, R.; GOMAA, M.;\& PURTON, S. Cyanobacteria as Chassis for Industrial Biotechnology: Progress and Prospects. Life, v. 6, n. 4, 42. dec. 2016.

16. KIM, T.; CHOI, W.-S.; YE, B.-R.; HEO, S.-J.; OH, D.; KIM, S.; KANG, D.H. Cultivating Spirulina maxima: Innovative Approaches. Cyanobacteria. 2018.

17. SOUZA, M.M. Potencial antifúngico, antioxidante e inibidor da síntese de aflatoxinas dos extratos fenólicos de Chlorella sp. e Spirulinaplatensis. 2007. 180 f. Tese (Doutorado em Engenharia e Ciência de Alimentos) - Escola de Química e Alimentos, Universidade Federal do Rio Grande, Rio Grande, Rio Grande do Sul, 2012.

18. COLLA, L. M.; REINEHR, C. O.; REICHERT, C.; COSTA, J. A. V. Production of biomass and nutraceutical compounds by Spirulina platensis under different temperature and nitrogen regimes. Bioresource Technology, v. 98, n. 7, p. 1489-1493, May. 2007.

19. VIGANI, M.; PARISI, C.; RODRÍGUEZ-CEREZO, E.; BARBOSA, M.J.; SIJTSMA, L.; PLOEG, M.; ENZING, C. Food and feed products from microalgae: Market opportunities and challenges for the EU. Trends in Food Science and Technology, v. 42, n. 1, p. 81-92, Mar. 2015.

20. LOURENÇO, S.O. Cultivo de microalgas marinhas: princípios e aplicações. São Carlos: RiMa, 2007. 606 p.

21. FIORE, M. F.; SANT'ANNA, C. L.; AZEVEDO, M. T. P.; JOMÁREK, J.; KAŠTOVSKÝ, J.; SULEK, J. \& LORENZI, A.S. The cyanobacterial genus Brasilonema, gen. nov., a molecular and phenotypic evaluation. Journal Phycology, v. 43, p. 789-98, July. 2007.

22. AGUIAR, R.; FIORE, M. F.; FRANCO, M. W.; VENTRELLA, M. C.; LORENZINA, A.; VANETTI, C. \& ALFENAS, A. C. A novel epiphytic cyanobacterial species from the genus Brasilonema causing damage to Eucalyptus leaves. Journal Phycology, v. 44, n. 5, p. 1322-1334, oct. 2008.

23. SANT'ANNA, C.L.; AZEVEDO, M.T.P.; FIORE, M.F.; LORENZI, A.S.; KAŠTOVSKÝ, J. \& KOMÁREK, J. Subgeneric diversity of Brasilonema (Cyanobacteria, Scytonemataceae). Revista Brasil. Botânica, São Paulo, v. 34, n. 1, p. 51-62, jan./mar. 2011.

24. DA FONTOURA, J. T.; ROLIM, G. S.; FARENZENA, M.; GUTTERRES, M. Influence of light intensity and tannery wastewater concentration on biomass production and nutrient removal by microalgae Scenedesmus sp. Process Safety and Environmental Protection, v. 111, p. 355-362, oct. 2017.

25. PEREIRA, M. I. B. Avaliação do cultivo mixotrófico da spirulinaplatensis (Arthrospiraplatensis) utilizando soro de queijo mozarella de búfala como fonte de carbono orgânico. 2017. Dissertação (mestrado em Produção Animal) - Universidade Federal do Rio Grande do Norte, Macaíba, RN, 2017.

26. FERNANDES, M. V. Análises dos parâmetros de cultivo da microalga Chlorellavulgaris. 2018. Dissertação (Mestrado em Ciências - Programa de Pós Graduação em Engenharia Química na Área de Desenvolvimento de Produtos e Processos) - Escola de Engenharia de Lorena, Universidade de São Paulo, São Paulo, 2018. 